\title{
COMMUNITY DEVELOPMENT IN ASIA
}

\author{
By Udo ERNSt Simonis
}

Fourteen nations were represented at the International Seminar on the Comparative Study of Community Development held in Seoul from 3rd-8th December 1973, and organized by the Korean National Commission for UNESCO: four economically highly developed countries (Denmark, Federal Republic of Germany, Japan, and USA), seven developing countries (Brazil, Ghana, India, Indonesia, Republic of Korea, Malaysia, and Thailand) and three countries which from an economic point of view occupy an intermediate position (Israel, Yugoslavia, and Poland). According to the vision and the goal of community development as defined by the United Nations Economic and Social Council, ". . . the term community development is the process by which the efforts of the people themselves are united with those of governmental authorities to improve the economic, social, and cultural conditions of communities, to integrate these communities into the life of the nation and to enable them to contribute fully to national progress". On this basis community development contains the following main elements: realization of a central political will (development plus national identity); points of departure are individuals and communities (the decentralized level); the objective is to enable (with state support) this decentralized level to self-help; the instrument is co-operation between the central administration and the decentralized level.

The idea, however, of what community development actually entails or should be about, widely differs from country to country. Referring to David E. Apter's keynote speech at the Seoul seminar ${ }^{1}$, three main practical models can be specifically identified:

(1) the Chinese model, where the goals and instruments of community development are very largely determined by the central administration and conceived for a nation which is used to collective behaviour and is organized collectively;

(2) the Indian model, which in following a neo-fabian, liberal tradition aims to produce common interest through the motivation of the individuals to selfhelp;

(3) the Tanzanian model, which tries to combine features of (1) and (2).

As fairly soon emerged, from the nations represented at the Seoul seminar only the seven developing countries actually do have community development programmes shaped along the lines of the UN definition. Most of them - though not all -would fall into Apter's second category. Some of the developing countries which would fall into the third category did not participate in the seminar. As the first category was also not represented, there was not much scope for a systematic comparative study of community development in general, or of the three categaries of community development models in particular, although the discussion did move mostly around these positions.

The conference discussion had several further limitations: it concentrated largely on rural development problems and on the developing countries only. This, on

1 Cf. Internationales Asienforum. International Quarterly for Asian Studies, Vol. 5, No. 3, München 1974. 
the other hand, led to a most interesting facet of the seminar: the representatives of the industrialized and urbanized countries were hardly in a position to contribute anything significant to the (in this way) reduced topic of community development - apart, of course, from highly intelligent but abstract comments and sophistries. One of these, made half-jokingly but with some accuracy: "The developing countries still have active communities but no adequate development, whilst the industrialized countries have got development but no functioning communities!“

Thus, during the seminar we came to see the conventional pupil-teacher pattern as ambivalent, when not reversed. Unfortunately however this idea could not be further developed, since the discussion concentrated almost exclusively on the actual problems of the developing countries and not on the historic experience of the industrialized countries.

One more consequence of the restriction of the discussion to rural development in the developing countries, was the almost total neglect of the problems in the urban areas. Contrary, in the country report on the situation in the Federal Republic of Germany, the main emphasis had been laid on the problems of the urban areas. Taking into account the daily increasing and almost insoluble planning problems in the urban areas of the developing countries - Seoul, the place of the conference being just one illustrative example - the consideration of this facet of community development in the seminar discussions would have been apposite and probably rewarding. This not being the case, one got the impression that the manifold problems of the large cities and built-up areas have hardly been grasped by the developing countries and have been given only a subordinate position in planning discussions.

From the German point of view and taking into account the German discussion, one was forced - perhaps and as is to be hoped, too soon - to come to the conclusion that the developing countries will repeat most of our mistakes and errors in urban development planning (as unco-ordinated housing construction and sprawling, priority for industrial zones, promotion of private means of transport, etc.). A wide field for comparative studies within the United Nations and UNESCO could be drawn from these points and is still left open.

In order to extend the above arguments, to show how community development is understood in Asia and where the approaches differ, we selected some of the country reports for publication in this journal; revised versions of the country reports on Republic of Korea, India, and Malaysia submitted to the Seoul seminar are printed below ${ }^{2}$.

Here, a few more words should be said on the seminar itself, which was given an enormous amount of publicity by the Korean Government and press. The Korean Government apparently feels that the rural population is the most important source of support for its policies and had, therefore, started a community development campaign (Saemaul Undong) in 1971, which in material terms is mainly a matter of dwelling modernization in the rural areas, including the construction of model villages in the planning regions. A "model village" which was prohibitively expensive was visited as part of the seminar. A congress on Saemaul Undong had taken place a few weeks before the UNESCO seminar,

2 Cf. the country report on Indonesia, in: Internationales Asienforum, op. cit., Vol. 5, No. 3, 1974. 
the policy declaration of which had been widely reported in the press. The role which the UNESCO seminar was to play in the formation of public opinion in South Korea must be seen in this light.

There were two main points of criticism among the participants about the seminar itself. During the discussions very little attention was paid to the reports from the individual countries. No attempt was made during the semiar to obtain a systematic comparison of these papers. The results of the discussions necessarily suffered from this.

There was, on the other hand, a wide consensus that a great deal of work need to be done on the basic conceptual and methodological dimensions of community development, that efforts must be taken to mobilize international and regional organisations to devote greater attention to this field of activities. In order to better achieve the goals of each country's community development programme and to improve the whole community development approach, the delegates in a final resolution recommend that several steps be considered by relevant United Nations organizations for future international co-operation:

- UNESCO and United Nations Development Programme (UNDP) are requested to promote a scientific review of experiences and exploration of ideas on community development;

- UNESCO and UNDP are requested to convene meetings to further identify needs and lines of activities with regard to concept, research and training in community development, with specific emphasis on clarifying social indicator systems for community development;

- UNESCO and UNDP are asked to support a survey of existing organisations active in the field of community development with a view to exploring the means for further concerted efforts of these organisations and also to examine whether there is need to establish a new regional (in Asia) or international institute of community development;

- International conferences of professionals involved in community development should be convened once every three years for the purpose of the advancement of knowledge in this field.

Not all of the above recommendations were accepted unanimously by the delegates to the seminar. However, the secretariat was asked to submit these recommendations to the 1974 general UNESCO conference. It remains to be seen whether community development will gain a new look and fresh support, and whether it can be based on a fundamental commitment to the reduction of domestic as well as international inequalities.

\section{Community Development in the Republic of Korea*}

\section{Introduction}

In Korea community development takes place in a rapidly changing social and economic setting. Although it is useful to describe the current character and level of community development, this paper basically presents the recent activities

\footnotetext{
* Revised version of a country report presented by Kim Il-chul at the International Seminar on the Comparative Study of Community Development, 3-8 December 1973, Seoul, Korea.
} 
by the government in the community development field. Specifically, the paper outlines the New Community Movement (Saemaul Undong), the Korean governments major effort in the community development field. Discussion of the New Community Movement, its goals, and remaining tasks, is prefaced by a short discussion of the history of community development in Korea and its place in the overall national development effort.

\section{Goals of National Development and Community Development Policy}

It seems a fair statement to say that, until the late 1960's, national development goals in Korea had been defined largely in terms of rapid economic growth through industrialization. Until the early sixties, the growth performance of the Korean economy was far from being impressive. But since 1963, there has been spectacular growth as the result of successful implementations of the First and Second Five-Year Economic Development Plans. A series of economic reforms in the 1960s spurred this growth. Many investments in education, training, in the infrastructure of the country such as transportation and communications, and in agriculture set the stage for a development pattern that included liberalizing of trade, increasing government revenues, fighting inflation, encouraging saving through interest rates and other economic measures. Thus, during the 1963-69 period, the average annual rate of growth of the GNP has been about 10 percent, and during this time the GNP has just about doubled.

The accomplishment of the high rate of economic growth in Korea was not without problems and strains. In fact, the problems and strains which became more clearly manifested by the end of the 1960 s were partly the products of the very process of economic growth. They were the problems and strains characteristic of those countries undergoing similar patterns of modernization and development process, e. g., rapid urbanization, large-scale migration from village to urban centers where industrial centers are located, a growing gap in the standard of living between the rural and the urban areas, growing cultural disunity created by the difference in the impact of direct exposure to foreign cultures.

The political implication of this gap is that it might become the primary source of political instability and a principal obstacle to national integration. And this concern was reflected in the overall objective of the Third Five-Year Economic Plan which emphasized a shift from heavy investments in industry and the industrial infrastructure to a larger allocation of resources to agriculture. To be sure, this strategic shift reflects the more immediate concern for the problem of selfsufficiency in rice production. But it goes beyond this immediate concern. For a country like Korea which sees itself engaged in competition with the Communist regime in the northern part of Korea, the underdeveloped nature of the rural sector of the economy takes on a significant meaning.

It is from this vantage point that one should view the recently accentuated effort on the part of the Korean Government to initiate a nation-wide community development program. There has been a variety of community development programs in Korea since the late 1950s. Various governmental agencies have initiated programs which operated more or less independently and in a disjointed fashion. But it was not until 1971 that the Korean government devoted its 
energy to this program on a national scale. This national policy which is being implemented in the name of the New Community Movement (Saemaul Undong) represents a significant turning point in the history of community development in Korea as well as an all-out-war, as it were, against the centuries-old, stagnant and poverty-stricken conditions in the rural part of Korean society.

\section{Historical Background of the New Community Movement}

Under the direction of the National Committee on Community Developmen (NACOM), established in 1958 at the central government level, the first wellorganized community program was launched with twelve pilot villages. Until these were integrated into the existing Agricultural Extension Organization in 1961, the community development programs had gradually expanded to cover 818 villages. With the enactment of the Agricultural Development Law in 1961, the Agricultural Extension Service and the Community Development Program were subsumed under the Office of Rural Development.

Near the end of the Second Five-Year Economic Plan (1971), government felt a much greater effort should be made in the rural areas to achieve more balanced growth in the Korean economy. Disappointed by the unsatisfactory results achieved by the existing methods of rural development and an inadequate organizational framework for implementing the program, the government, especially President Park himself, began to take an active initiative in reorganizing the organizational framework so as to bring a more drastic and fundamental change in the rural sector of the Korean economy.

Unlike the previous agencies which had given sole emphasis to agricultural productivity, the government sought from the beginning to put more emphasis on attitudinal re-orientation of the people in the rural areas. The government seems to realize the importance of the need to encourage the rural populace to realize that they alone are able to improve their own conditions and surmount many obstacles facing them. The role of the government is perceived as that of injecting a stimulus to their efforts by providing material as well as necessary administrative support. The Ministry of Home Affairs has been entrusted with the major administrative responsibility for overseeing the implementation of the movement. Commanding an effective administrative machinery as well as large manpower, the Ministry is now on the forefront of this New Community Development which may be described as a determined march toward the goal of prosperity and betterment of our rural community and the nation as a whole.

\section{Organizations and Institutions for the New Community Movement}

The Office of Rural Development which is under the Ministry of Agriculture and Fisheries has organizational components of the Program Coordination Office, Research Bureau, Technical Difussion Bureau, and Rural Guidance Bureau. There are nine Provincial Offices of Rural Development. The Office of Rural Development headquartered in Suwon now has 790 people employed, including research staff. At the provincial level 845 staff and at other lower levels 5760 workers are working for this office. 
Responsibility for the New Community Movement is not only held by the Ministry of Home Affairs, government officials at all levels of administration have been heartily involved in all phases of the program including planning, implementation, and mobilization.

From October 1970 to May 1972, government assistance for the Movement totaled almost 8 billion won (roughly corresponds to 20 million US dollars) and in 1972, when peoples' labor and sharing are accounted, the total expenditure amounts to 33,8 billion won. The government was prepared to spend 45 billion won for 1973 alone. All other ministries of the government are required to give full support to this movement. For a closer coordination among different ministries, the Central Coordination Committee was formed at the cabinet level and the Committee has been chaired by the Minister of Home Affairs. Similar organizations have been created at all the local levels. In the village, the New Community Development Committee was organized.

There have been, of course, many other institutionalized agencies for rural development. The National Agricultural Cooperative Federation which is functioning under the supervision of the Ministry of Agriculture and Fisheries is operating on a national scale with a staff of 10,000 employees. The Korea Credit Union League jointly started by Sister Mary Gabrielly and the Cooperative Education Institute has 151,740 individual members and 715 branch unions in the country. There are also numerous private agencies devoted to Community Development in the country. Among them are such well known projects as Village Microlibrary Movement, Cooperative Education Institute, Canaan Farmers' School, Community Development Foundation, Korea Farm Village Cultural Research Institute.

\section{Policy-Making Processes in the New Community Movement}

As far as policy making for the movement is concerned, the Office of the President has been as deeply involved as the Ministry of Home Affairs. All final decisions related to the program have been largely made in the President's office. The President himself established many general guidelines for the Movement and all the ministries interpreted these and developed detailed programs to be implemented.

A package of basic development programs came out as standard and basic guidelines for the Movement. Each village, with their own decisions made by the New Community Development Committee, is supposed to carry out its own programs along this package guidelines. While certain projects are selective, the basic projects, such as roof replacement and strainghtening roads, are designed to be implemented throughout the nation.

The Ministry of Home Affairs, particularly, which is administratively responsible for the Movement, has developed various policies and rules for the successful execution of the Movement. The policy making process is thus very much centralized as far as the Movement is concerned. Even at the local level, the situation is much the same. Chiefs of the local governments are the primary policy makers following instructions from the central government. 


\section{Programs and Activities for the New Community Movement}

Because of the emphasis on value change among the rural portion of society, educational programs were as important as economic and social development efforts. The Ministry of Education developed a series of programs for $\mathrm{New}$ Community Education. Numerous and fairly extensive training programs have been provided for farmers and teachers. Extra-curricular activities and even textbook teachings have been purposefully related to the spirit and principles of the Movement. All educational training programs are directed toward the achievement of the three basic principles of the Movement, that is, self-help, industriousness, and cooperation. Because the community school had already been established, the Ministry encouraged people to utilize the school as the center of the community and to make schools available for the program as much as possible. University students have been encouraged both by the government and the university for their village service programs during vacations.

Programs and activities of the New Community Movement are extensive, covering education, agriculture, construction, cultural, and social activities. The contents of the programs can be classified under three headings:

\section{(a) Spiritual Enlightenment and Rationalization of Living}

As evidenced in the three basic principles of the Movement, many educational programs have been devoted to re-orientation of the peoples' attitude. In order to implement these goals, training courses, conventions, demonstrations, exhibitions, film shows, and many other methods have been attempted. Not only through classes and meetings but also through actual participation in chorus, cleaning streets, visiting advanced villages, and a variety of projects in the village, a change of attitude has been continuously sought. Encouraging a simple and diligent life, savings, and simplification in the practicing of traditional customs such as wedding and funeral ceremonies, the government has encouraged value changes.

\section{(b) Environmental Improvement}

The government began the program with a belief that change in the environment gives rise to change in attitude. Although the reverse is also true, an improvement of external conditions has been thought as a more dramatic and attractive inducement for attitudinal change.

Programs directed toward this end include electrification, highway construction, construction of river banks, straightening farm roads, replacement of thatched roofs by tiles, drainage systems, drinking water, improved latrines, public bath houses, public laundry places, improved cooking facilities, children's playing grounds, improved house walls, and other village beautification projects. Some of the projects are supported by government grants-in aid and some by government loan. All labor required for the projects except highly technical matters are provided by the villagers themselves. 


\section{(c) Farm Income Increase}

After the initial focus on environmental aspects, emphasis has gradually shifted to the improvement of farm income. Agricultural programs thus came to play a very important part in the New Community Movement. Accordingly, all agricultural policies planned by the Ministry of Agriculture and Fisheries became an integral part of the policy making for the Movement.

All agricultural and economic programs and policies have been aimed at raising farm and side-farm incomes through improved productivity and introduction of small scale and family industry in the rural scene. For example, programs include land consolidation, irrigation, high yielding variety of crops, mechanization, processing of agricultural products, farm industry, utilization of waste land and mountains, animal husbandry, fisheries, technical innovation, improved market system, improved transportation, loan programs, etc.

One of the most interesting aspects of this New Community Movement is that there is no single professionally paid worker for this program. The government officials, village workers, and school teachers are involved as workers, leaders and encouragers of this Movement. Officials from the top ranking provincial governments to the clerks of town offices, and all other civil servants working in the related agencies, are given specific assignments and responsibilities in the Movement.

Each official is given targets and expected to achieve these goals. If the goals are not met, he is seriously critized. It is thus civil servants in the local government who assumed all responsibility for the program. Competition has also been encouraged through the provision of rewards and prizes for those who exceed their goals. As a consequence there has been very keen competition among different provinces and countries and between their respective local governments. It also created the same competition between villages.

Village leadership for this Movement has been carefully developed, sometimes by the local government and sometimes by the villagers themselves. The type of leadership has been regarded as the most essential factor for the success of the program. The government has invested a very large amount of money for the leadership training at all local levels.

Evaluation teams consisted of experts and inspection teams of responsible officials were regularly sent out to check the progress and to collect first hand information concerning problems in the field. Their reports have been channelled into policy makers, and mismanagement and inadequacy of projects are often corrected by them on the spot.

\section{Results}

There are numerous reports on the achievements of the Movement. Government statistics reveal that from October 1970 to May 1971 a total of 7,2 million farmers had participated in the various projects for the New Community Movement; 5884 hectars of mountains have been planted with trees; 6466 kilometers of village roads were constructed or expanded; 519 kilometers of river banks were built; 65,400 public wells and 24,190 laundry places were repaired or constructed, 
and many other impressive results have been attained. The same source also indicates that from June 1971 to 1972 a total of 22,700 villages and about 13 million villagers participated in the Movement.

Perhaps, the greatest of the products of this Movement is integration of the segments of society. The rural society and farmers have been largely neglected from the standpoint of national community and national concern. Through this Movement farmers have been encouraged and their problems received national attention.

Although it is too early to fully evaluate the impact of the community development effort, the present rural communities, when compared with several years ago, clearly present a picture of significant change. Not only their physical and external features but also their general standard of living and incomes have been significantly improved. The rural people appear more optimistic about their future. Agricultural productivity has been sharply increased. There is more electricity and mechanization. There are less shortages of water. Small scale industries are being actively introduced into the rural setting. The transportation system is being enlarged. Market systems and management have been significantly improved as well as agricultural techniques. More students are enrolled in higher level schools. More radios and television sets are readily available. Illiteracy is almost disappearing. The bicycle and tricycle are easily available. The prices of agricultural products are stabilized and more advantageous than before.

\section{Problems of Community Development}

Material results are, of course, important in the process of community development. But a central question is how to ensure social and cultural development as well as economic improvement. These value related problems are key components and are vital in community development.

\section{(a) Participation}

The first point is the problem of the degree of government leadership versus voluntary participation in the program. The New Community Movement in Korea can be characterized as a government-induced movement. Government officials were the leading elements in the initial stage. More recently, however, as voluntary actions by the people have slowly emerged, the government has gradually withdrawn.

The strategy pursued by the government was to initially direct the planning and change effort at the village level. The assumption here is that initial successes will result in significant value change leading to voluntary participation in community development activities. The initial results appear encouraging, but the question remains whether or to what extent this will prove to be an effective strategy. 


\section{(b) Leadership Patterns and Community Organization}

The next point to be raised from the Korean experience is the quality and type of leadership in the village. One of the impacts of this Movement on the leadership pattern in the village was the development of individual leaders with strong initiative. Such phenomena would be fairly natural when ambitious programs are launched with a great speed, magnitude, and intensity. Achievements by these early leaders are a most decisive factor for a successful movement.

The question here concerns the institutionalization of leadership patterns capable of continuing the community development program launched by the $\mathrm{New}$ Community Movement. Initially, the government has attempted to emphasize the importance of individual leaders. However, leadership structures which are more congruent with existing group oriented village level structures must be developed in the future.

\section{Suggestions on Regional and International Coordination}

To continue and build on the work accomplished by this seminar it might be fruitful to recommend the establishment of an ad hoc Council on Community Development. Such a council would develop guidelines for the establishment of an Institute for Community Development. The council would review existing community development programs and develop a specific research and goals agenda for the proposed institute.

Following the work of this ad hoc council, we recommend establishment of an Institute for Community Development under the auspices and with financial support from relevant United Nations organizations. This institute would thus serve to carry out the needed basic research suggested by the ad hoc Council, carry on the information exchange function by institutionalizing the indicator system concept, and provide international training for community development officers. For example, by developing indicator systems out of standard census information and social statistics which allow the monitoring of the impact of community development programs on their target groups, national leaders may comparatively evaluate the success and failures in their own community development programs and make the necessary adjustments. We think this institute would provide the critical people to carry out these much needed communication training and research activities which would greatly support the efforts of individual countries community development programs. 


\section{Community Development in India}

\section{Goals of National Development Policy}

The basic premise of India's planning has been development along socialistic lines to secure rapid economic growth and expansion of employment, reduction of disparities in income and wealth, prevention of concentration of economic power and creation of values and attitudes of a free and equal society.

Economic development in the last two decades has generated new forces of growth resulting in per capita increase of incomes, yet unless the problems of unemployment and income distribution are tackled directly, it may take years for the poorer sections of the people to reach the minimum consumption levels. It will be neither feasible nor desirable to contemplate such a long waiting period.

India's Fifth Five-Year Plan, now in the making, takes into account the historic inevitability of making a direct approach to reducing poverty. The present government had won a massive mandate from the people on the basis of a programme whose centre-piece was "Garibi Hatao" or remove poverty. The Fifth Plan is but a step in that direction. In a predominentaly agricultural country the main attack has to be in the rural areas where $75 \%$ of the population is connected with agriculture. Less than half of the rural poor are landless labourers and a little more than half are small and marginal farmers.

\section{Community Development}

The basic objective of the Community Development Programme launched in 1952 was to secure full development of the material and human resources on an area basis and thereby raise the rural community to higher levels of living with the active participation and, as much as possible, on the initiative of the people themselves. This basic objective has not undergone any significant change, though there might have been some variations in emphasis in the programme aspects of Community Development.

In recent years, special agencies have been inducted to carry out several new schemes to meet some immediate situations such as relieving rural unemployment or helping small and marginal farmers. To what extent this might have cut across the long term view of integrated area development is a question that might demand new answers.

\section{Historical Background}

When India became independent, it was imperative to bring the small communities of villages into the democratic structure with a view to moulding their thoughts and behaviour into patterns compatible with the modern age. The constitution laid down: "The State shall strive to promote the welfare of the people by securing and protecting as effectively as it may, a social order in which justice,

\footnotetext{
* Revised version of a country report presented by N. A. Agha and S. M. Murshed at the International Seminar on the Comparative Study of Community Development, 3-8 December 1973, Seoul, Korea.
} 
social, economic and political, shall inform all the institutions of national life". The Community Development Programme was a step towards the realisation of that objective. It was defined by UNESCO as "the process by which the efforts of the people are united with those of the governmental authorities to improve the economic, social, and cultural conditions of communities, to integrate these communities into the life of the nation and to enable them to contribute fully to national progress". Activising the individual and the community to strive for self-improvement, making use of the available government assistance, but dependent largely on self-help, is its central purpose and people's participation is the key-note of its programme.

The Grow More Food Enquiry Committee (1952) observed that all aspects of rural life were inter-related and that while particular problems might call for special attention, the plans for them should form parts of and be integrated with those for achieving the wider aims. The recommendations of this Committee were responsible to a large extent in shaping the extension approach which became an essential vehicle of the Community Development Programme in India. It was felt that if the central aim of community development was investment in man, an integrated extension service should be the principal means to that end and that knowledge and techniques should be carried to the people through the extension agency. The First Five-Year Plan gave recognition to this new approach in the following words: "Community Development is the method and rural extension the agency through which the Five-Year Plan seeks to initiate a process of transformation of the social and economic life of the villages."

\section{Organisations and Institutions for Community Development}

The programme of Community Development evolved through a series of stages, its central theme of self-reliance remaining the primary consideration. As at present constituted the programme is taken up in a Block of about 100 villages each in two stages. The first stage of 5 years has a nucleus budget of Rs. 1,2 million and the second stage, again of five years, has a provision of Rs. 500,000. The post stage II blocks are required to depend more on their own efforts and local resource mobilisation. As a coordinating agency it can always take optimum advantage of activities of development departments and local bodies.

The total number of blocks in India is now 4,890. The staff pattern in a C.D. block is: (1) Block Development Officer, (2) Extension Officer Agriculture, (3) Social Education Organisers (men and women)/Extension Officers Panchayats, (4) Extension Officer Cooperation, (5) Extension Officer Animal Husbandry, (6) Extension Officer Village Industries, (7) Gram Sevaks or Village Level Workers, (8) Mukhya Sevikas and Gram Sevikas (lady village level workers), (9) Medical Officer, (10) Overseers, (11) Progress Assistants. This block staff is to assist the people to meet their needs and has to operate through group organisations such as cooperatives, farmers forums, youth clubs and women's organisations. Such organisations have been formed in blocks all over the country.

The Community Development Programme from the beginning took steps to ensure people's participation by organising non-statutory committees at the 
village and block levels but it was discovered that enthusiasm and participation of the people tended to be slow in forthcoming. Consequently, a team set up by the Government of India recommended the creation of an inter-connected system of democratic institutions at the village, block and district levels.

It also suggested that there should be genuine transfer of power and responsibility to these institutions, that adequate resources should be transferred to them, that all development programmes at these levels should be channelled through them and that the system evolved should be such as would facilitate progressive evolution and dispersal of power and responsibility in the future. This three-tier structure, known as Panchayati Raj now extends to all the Indian States with the exception of a few.

\section{Policy-Making Process in Community Development}

The village panchayat is the primary institution which is responsible for drawing up development plans. These village council programmes are then discussed at the level of the Panchayat Samiti (block council) for the formulation of block plans. Such a process helps the village panchayat to involve the people to face their problems realistically. The associated organisations mentioned above, assist in this exercise.

The block council in turn gets assistance from the Zila Parishad (District Council). At the State level the Department of Community Development under the charge of the State Development Commissioner or the Agricultural Production Commissioner maintains a two-way relationship with the Centre, or the Union Government, receiving national programme guidance from it, reporting progress and making suggestions about programme modifications to the Centre. The State Department also provides the coordination point for harnessing, and guiding all the technical services of the State Government required for the block programmes and to assure that each training centre and each block is properly supervised and staffed. The State Development Commissioner also maintains an administrative relationship with the District Collector and the Zila Parishad in planning, coordinating, executing and evaluating the work of each of the organised Community Development blocks in a district. Incidentally, the District Collector is assuming the position of the key administrative development officer working under the direction of the Zila Parishad. Assisting the collectors in carrying out their development responsibilities are staff of technical specialists assigned to the district by the various technical Ministries and Departments of States.

\section{Programs and Activities for Community Development}

The main sectoral emphasis of community development is on improvement of agriculture and ancillary services, like animal husbandry and irrigation, which employ about 75 per cent of the rural population. The development of smallscale industries also receives attention for creating more employment opportunities. Other features of the programme include the provision of basic amenities like drinking water, village primary schools, communications, adult literacy, social education and the promotion of community organisations. 
Stress is placed on the importance of training agriculturists, artisans and extension workers of various kinds for the proper implementation of the programme. But the most important is the change in the mental outlook of the rural people, instilling in them an ambition for higher standards. Thus Community Development is essentially a human problem of changing the outlook of 70 million families living in the countryside.

Though agriculture has been in the forefront of the Community Development programme, small farmers and marginal farmers who form the large majority of the peasantry in India have not been able to take advantage of the new technology due to various reasons such as lack of timely credit, crucial inputs and necessary advice. Special agencies have been created to help them. The extension organisation in the blocks being closest to the farmers is involved in the work of these agencies such as identification of the beneficiaries, preparation of production plans, arranging the liaison between them and the sources of credit and other inputs.

\section{Participation of Community Members}

The Block Development Officer is the captain of the development team guiding the staff in their working relations with each other and the Village Panchayats (councils) and Panchayat Samitis (block councils). The chief of the village panchayat and other village leaders are expected to guide village panchayats in examining village problems, and in deciding which problem to tackle as well as when and how to tackle them. In fact, no block staff can possibly succeed to the fullest in his job of being a friend, philosopher and guide to the village people unless his orientation is to work with the village people through the leader of the panchayat and to encourage and assist in the development of new leaders. While working with the villagers he reaches a consensus of village thinking about:

Who are the cultivators who should be approached for introducing a new variety of seeds?

Which villager would be the best leader to organize a village young farmers' club?

Who would be the best to organize village recreations programmes?

Who will be able to provide leadership for building a village school?

Who would be helpful in propagating the idea of family planning?

Who would be able to organize villagers for literacy education?

Who is the best one to guide the village women to come to decide programmes for village women etc.

In short, the block staff is working with the leaders of the villages. They are discovered, trained and brought into the panchayats, cooperatives and other village institutions and organizations that the Community Development has succeeded in developing. In fact the panchayats have formed functional committees or sub-committees like Mahila Mandals or women's organizations, Yuvak Mandals or youth forums and utilising them for Community Development activities. For example, after the school is opened in the village, the women's organization should create an atmosphere so that mothers take a lead in sending their children to the school. 


\section{Leadership Patterns and Community Organization}

A village without its own organizations and institutions cannot think, plan and act as a village unit. A block staff that fails to purposely sow the seeds and carefully nurture into being village organized groups, will miss its opportunity to assist the people in gaining experience in doing things for themselves under the stimulus of their leaders and working through their own organized groups. A realistic appraisal of village India makes clear that voluntary group effort is a part of the values and traditions of India.

The efforts of the voluntary groups are aided and encouraged by the block staff to assume responsiblity for village programmes and activities which fall within their interest. Village activities, as youth programmes, organized activities and programmes for village women, village farmers' associations and village recreation programmes to mention but a few are effectively developed and carried on over a long time basis through such voluntary village organizations.

\section{Support and Cooperation from Administrative and Local Organizations}

Carl C. Taylor while studying India's Community Development Programme said: "No country has so definitely planned that its national development shall be accomplished by Community Development methods as has India. No country has, therefore, greater need for all that is known about method of group formation and community mobilization." While mobilizing the community for the successful implementation of the Community Development Programme, the following ten questions have been kept in mind:

(1) How can the maximum number of villagers be mobilised for undertaking both village and national improvement projects?

(2) How can village communities be helped to develop self-perpetuating units of social action?

(3) How can solidarity of and loyality to local groups and local communities be developed?

(4) How can old established local groups be used to further the prescribed objective of national development?

(5) How can the level of aspirations of both individuals and local groups be raised?

(6) How can participation of traditionally low strata persons be increased in local projects?

(7) How to dissolve or in some way make constructive use of local factions or other divisive local groups?

(8) How to educate local leaders who can help develop local responsibility and initiative?

(9) How can the Centre and the State Governments make maximum contributions of money and personnel to local projects without diluting local group initiative and responsibility?

(10) To what extent and by what means and methods can the highest degree of traditional village culture be preserved, and at the same time how to face village 
development problems and issues which in the past have been beyond their social and mental horizons?

As to the support and cooperation from related administrative and local organizations, we first would like to quote from the United Nations Community Development Evaluation Mission in India, 1958-1959:

"As regards the lines of communications between the top level and the village level, they exist administratively, in the ordered hierarchy of official responsibility for action worked out in detail - in far too great detail - at every level. There may, however, be some lack of understanding among the top level officials about how to transmit their thinking about community development to all the officials below them, or the very size of the official community development machine may make this particular kind of communication difficult; at any rate, the existing lines of communication seem to be blocked. Many, perhaps the majority of, community development officials are, on the whole, out of touch with village expectations. Officials regard their function as being mainly to instruct and to 'organize', and seldom to sit patiently and listen until the slowly-formulated realistic thoughts of the villagers come to the surface. This patience and capacity for listening to villagers is brilliantly demonstrated by some of the very top level officials. But while they sit quietly and wait for the villagers to speak, a flock of minor officials buzz around, wanting to demonstrate their activities, to push plans and figures under the eyes of the high official and prove that they have been 'on the job'."

India's five-year plans have laid constant emphasis on the need for maximum community support and participation in programmes of development. The Approach Paper to the Fifth Five-Year Plan, which will come into operation in 1974, specifically mentions:

"Success in this worthy struggle (against poverty, dependence and stagnation) calls for discipline, hard work and sacrifices from all sections of the population. In order to ensure that these are forthcoming in the required measure, there is need for active involvement of the people in the formulation and implementation of the plan. The involvement of youth on a massive can bring about a qualitative improvement in implementation. The Fifth Plan must be truly a people's plan in every sense of the term."

We have to appreciate that this approach is of positive advantage, if not indispensable, even for the production effort, particularly in the field of agriculture. While the actual producers may be vast numbers of individuals and families, agriculture cannot flourish unless it has community support. It is the village community which has to draw up the village production plan and ensure, for instance, that the available inputs are properly distributed and utilised, that full advantage is taken of irrigation facilities and that on the whole the climate is favourable for the introduction of innovations and modern practices.

Family planning is another field which, in the ultimate, is of private character and yet the programme cannot succeed unless it has the general acceptance and support of the community. In the Indian rural social situation there is another field in which community responsibility and action have to be underscored. Special steps are called for to safeguard the interests of the economically and socially underprivileged people and to undertake special programmes geared to 
meet their particular needs and to accelerate their advancement. Programmes for small and marginal farmers and agricultural labourers or the Crash Scheme for Rural Employment which are intended to provide supplementary employment to the rural unemployed and under-employed, the Applied Nutrition Programme which brings special benefits to the nutritionally backward and vulnerable sections like the preschool children and pregnant women, the tribal development programme and special programmes for rural women and youth would fall in this category.

\section{Leadership Training}

Community organisation implies moulding attitudes for group activities to improve the quality of living at the local level. This calls for concerted efforts on the part of all government agencies and the people, technicians and opinion moulders and publicists. To get their willing cooperation, training assumes a crucial role in the scheme of Community Development.

Any such training programme will have to keep in mind the categories of personnel to be trained, the measure of their responsibility and the conditions in which they will have to function. Thus Community Development workers are extension agents functioning either as a catalyst, a stimulator or an educator or a technician or a specialist. These roles may be combined in varying degrees and the training programmes will have to be tailored accordingly.

In India the Block Development Officer is the captain of the team of subjectmatter specialists at the block level and looks to administrative matters; he has to have an overall knowledge of the entire programme. The Social Education Organiser, being a specialist in community organisation, is the king-pin of the movement; he has to be thoroughly grounded in the use of mass communication techniques. The Village Level Worker, as a representative of the entire team too requires an overall picture of the programme, though not of a specialist nature.

A question has often been asked whether there should be a 'common content' of training for Community Development workers. Broadly, the content of this training can be divided into that which is intended to give the workers the necessary background knowledge, that which will promote in him certain skills needed, and that which will mould his attitude in the right direction. It will be distinguishable from training which will give specialised knowledge and skill needed for particular services.

In India we have divided it into orientation training and job training. The 'common content' will draw on disciplines like social psychology, sociology, cultural anthropology, economics and public administration. Each discipline's contribution and its practical application are questions difficult to answer and will have to be with reference to the educational background, level of functioning and specific responsibilities of the different classes of workers. All this makes it obvious that the syllabi will have to be comprehensive. Difficulties, however, arise when an attempt is made to cover these in too short a period.

In India the rapid pace set for the expansion of the Community Development programme has led to the training of a very large number of extension workers within a tight time-schedule. This sort of an approach has not been beneficial and 
can leave large gaps in the initial period of training which should help in stimulating and guiding the process of self-education in the trainees. True, refresher courses at periodical intervals have contributed to filling the gap to an extent. Such courses are particularly important in the technical fields where new research knowledge has to be continuously passed on to the field workers.

In India a large number of training centres are functioning for various categories of personnel, both official and non-official. While organising these centres care was taken that these did not lose touch with the programme in the field. Otherwise there was the danger of their becoming too theoretical and removed from practical problems faced in the field.

The Presidents and Vice-Presidents of Panchayats and the members of Panchayat Samitis are trained in institutions at the district level run mainly by non-official organisations. The members of Panchayat Samitis are trained for a shorter duration by peripatetic teams of instructors sent from the training institutions. Short duration camps and seminars are also arranged as a part of the training programme for them.

\section{Apex Body}

For the orientation of the people's representatives, senior administrators and technicians and other personnel, the Union Department of Community Development has established a National Institute of Community Development. The aim of the Institute is primarily to stimulate thinking and give an opportunity to the participants to study literature on Community Development and related subjects. Advantage is expected to be derived from discussions and free exchange of views and information among the participants who come from different parts of the country and from different fields of work.

The Institute also functions as an apex body for providing orientation in ideological concepts, philosophy and methods of Community Development and Panchayati Raj (democratic decentralisation) and conducts specialised courses concerning different areas of rural development and social change. It also organises seminars and conferences in collaboration with other organisations and ministries. It provides academic guidance to the training centres run by different States, and imparts the necessary training in teaching techniques and methods to the staff of these training centres.

We have rather dwelt at length on the steps taken in India for the training of extension personnel. In fact, the magnitude and importance of this aspect was realised from the very beginning. The requirements of official workers (all categories) under the C. D. programme are estimated at 200,000. Moreover it is estimated that in the system of Panchayati Raj (three-tier structure of local selfgoverning bodies) nearly 2,5 million elected representatives will need study facilities to gain knowledge of this programme. And the attention paid to this work drew from the Report of the United Nations Evaluation Mission the remark:

"Probably no single aspect of Community Development work in India has received more attention than the need for, and the way to carry out training schemes. Other countries less advanced than India in establishing a Community Development movement to raise the standard of living in rural 
areas, will find the history and development of training schemes in India, even over the short period since the first project began, of great value in establishing their own schemes. No small part of the value will lie in examining the criticism and evaluation of training schemes by Indian and foreign experts."

\section{Regional and International Cooperation}

We have quoted the above excerpt not only to reiterate the importance of training and research in Community Development but to suggest that training is one of the areas in which regional and international cooperation should be welcome. The experience at the Indian National Institute of Community Development has shown how research has helped in making field programmes meaningful. The National Institute through its field research work has many a time suggested ways and means by which particular aspects of a programme could be accelerated, especially in a country which cannot admit of uniform functioning. We are wondering whether work of this nature could be enlarged to cover bigger areas. Perhaps, an international institute on Community Development could be established in the South East Asian region. It could serve as the clearing house of thinking on Community Development in the participating countries. These facilities will help particularly those countries where research and training have not attained the desired stature. An institute of a permanent nature could help in the follow-up action of the various suggestions and conclusions reached at periodical gatherings, as also to evolve new strategies to revitalize the C. D. programmes in the changed context of today.

\section{Conclusion}

Before closing we may dwell on as to how these comprehensive socio-economic programmes of Community Development in India work out in the field. Frankly speaking, the Community Development programme adopted as the prime instrument of harnessing the resources of the people and of government for a concerted effort towards rural development is at a low ebb. The almost total denudation of funds for community programmes, coupled with the abolition of functionaries whose primary task was to stimulate community action, has meant a virtual jettisoning of the basic concept of integrated rural development. Both Community Development and local-self government are as a result in eclipse.

What are the factors which have led to such a situation, not only in India, but, we believe in some other parts of the world as well. How is it that when lip sympathy continues to be paid to the value and importance of the Community Development approach, the programme has become bereft of its original meaningful and responsible role?

To find the answers we must go back to the genesis of the programme and take a fresh look at the basic premise underlying the community development approach: 
(1) Has the necessary degree of coordination and cooperation been forthcoming from the various departmental agencies envisaged in the integrated approach under the Community Development programme?

(2) Has the people's involvement and commitment to the programme fallen short of expectations?

(3) Have the rural youth been activised to the extent possible?

(4) What should be the approach and strength of the C.D. programme to pursue a meaningful programme, if it is to maintain the original postulates which still remain valid? 


\section{Community Development in Malaysia}

\section{Background}

Malaysia covers an area of about 130,000 square miles, occupying the Malay Peninsula (52,000 sq. miles) and the northwestern coastal area of Borneo Island ( 78,000 sq. miles); the two regions are separated by about 400 miles of the South China Sea.

The population of Malaysia as of August 1970 was 10,439,530 with nearly 9,000,000 in the peninsula. It consists of three main races, $56 \%$ Malays and other indigenous native groups, $34 \%$ Chinese and 9\% Indians. Of these, 7,651,600 live in areas designated as rural with the remaining 2,787,900 living in areas defined as urban (population 10,000 and above). In other words, about 5 out of 7 persons in Malaysia live in rural areas.

The distribution of the various community groups between urban and rural parts of the country varies. Among Malays and other indigenous groups combined, both in the peninsula and the states of Sabah and Sarawak, $93 \%$ live in rural areas. Even in the more urbanised Malay Peninsula, only $15 \%$ of the Malays live in urban areas. On the other hand, among Chinese and Indians, $46 \%$ and $35 \%$ respectively live in the urban sector. This identification of racial communities with particular geographical locations and certain economic or occupational functions (and thus, imbalance), has brought the Malaysian government to launch a bold economic policy known as the New Economic Policy.

The New Economic Policy has twin objectives, the eradication of poverty, irrespective of race, and the restructuring of Malaysian society in order to correct racial economic imbalance. This is consonant with the aspiration of the nation as enunciated in the Rukunegara (Pillars of the Nation) to create a just society in which "there is a fair and equitable distribution of the nation's wealth". Accordingly, the formulation of programmes and strategies in the Second Malaysia. Development Plan has been guided largely by the New Economic Policy. In presenting the motion on this plan in the House of Representatives on July 12, 1971 the Prime Minister, Tun Haji Abdul Razak bin Hussein, said:

"From now on and in the ensuing years, our task and responsibilities are to create a new society with a new image and spirit, based on the policies and strategies in the Second Malaysia tenets of the Rukunegara. The principles and objectives laid down in the Rukunegara are not intended only for the next ten or twenty years but they are the guiding principles for Malaysia in the future. We, who are here today, should feel proud of the golden opportunity entrusted to us to make Malaysia an invaluable inheritance to the future generations in which everyone will benefit the prosperity, peace and stability. And everyone should have a deep personal satisfaction in pursuing his vocation according to his merit in an independent nation. These are the objectives of a society that is just and equitable - a society with a modern and progressive outlook comparable to other advanced nations in all fields of endeavour in this age of modern science and technology."

$\because$ Revised version of a country report presented by A. B. Esa and O. S. Cassim at the International Seminar on the Comparative Study of Community Development, 3-8 December 1973, Seoul, Korea. 


\section{Goals of Community Development}

Bearing in mind the social and economic background of Malaysia as described above, it is logical to state that the goals of community development in Malaysia should be consistent with the desires and objectives of the nation as described in the Rukunegara, the New Economic Policy and the various Development Plans.

The general objectives of community development programmes in Malaysia are as follows:

i) Achieving the advancement of the individual who is a Malaysian citizen;

ii) Achieving the progress of a community by encouraging its membres to cooperate so that they are ready to act for the advancement of their community in the context of national progress;

iii) Achieving the social and economic progress of the Malaysian society as a whole based on the Rukunegara and the New Economic Policy.

The more specific objectives of the community development programme can be summarised as follows:

i) To achieve national unity by developing understanding and cooperation among all classes of people and ethnic groups;

ii) To eradicate poverty and to achieve economic and social advancement of the people through economic means, education, health and attitude;

iii) To instill patriotism and willingness to establish a Malaysian culture based on the culture of the indigenous groups;

iv) To stimulate motivation and the people's effort and involvement for the success of community development schemes;

v) To modernise the rural sector;

vi) To streamline and coordinate the implementation of community development programmes so as to be more effective.

\section{Historical Background of Community Development}

At a conference on Community Development in Taiping, Perak in 1953 (prior to independence), the government had adopted the following definition: "Community development is a movement designed to promote better living for the whole community with the active participation and on the initiative of the community."

The above concept was accepted during a period of emergency when the country was fully engaged in the war against the communists. Between then and independence (1957), the community development programme became the concern of three ministries only. The programme did not make much headway principally because of lack of cooperation among the operating ministries, and also the people had not fully understood this new concept of development. Community development projects were carried out only in certain selected villages on pilot basis.

With the lifting of the emergency in 1960, the government was able to divert public expenditure to provide physical infrastructure in the rural areas. The Ministry of Rural Development then embarked extensive and numerous projects to build schools, clinics, roads, drainage etc., for the rural population. In 1962 the 
government moved on to the second phase of its rural development programme by issuing Directive No. 3 which established the JKK - "Jawatankuasa Kemajuan Kampung" (Village Development Committee) - to encourage the participation of the local people. After providing the necessary infrastructure in the rural areas, the government felt it was time to intensify the involvement and participation of the people in development programmes.

In 1966, the first year of the First Malaysia Plan, "Gerakan Maju" (Operation Progress) was launched. A guide book was issued to the Village Development Committees as a supplement to Directive No. 3. It suggested each community to plan development programmes in order to solve the following interrelated problems: poverty, lack of education, sickness, and apathy.

Because the emphasis in the First Malaysia Plan was on economic development, "Gerakan Jayadiri" (Operation Self-success) was launched in 1968 to remind the people that the main thrust of a community development programme was also on their economic advancement.

Following the tragic events of the racial clash in May 1969 there was a radical change in the government's thinking on development. Rukunegara (Pillars of the Nation), the New Economic Policy and the Second Malaysia Plan describe the new spirit and directions of the society. Community development in Malaysia then has to be related and geared to these goals and objectives. By so doing, Malaysia in fact fully adopts the definition of community development prescribed by the United Nations.

On August 6, 1972, the Prime Minister, Tun Razak, launched "Gerakan Pembaharuan" (Operation Renewal) at Dungun, Trengganu when he declared open the Trengganu Community Development Exhibition. Gerakan Pembaharuan was launched to intensify further the community development programme which had conspicuously been lagging after 1969. "Operation Renewal" was named so for the following reasons:

a) renewal of effort to make community development succeed;

b) renewal of objectives aligned to national aspirations and policies;

c) renewal of attitude of the people to cooperate and respond more positively with the government;

d) renewal of attitude of government officers to always give priority to people before self and organization;

e) renewal of community development administrative structure so that there is better coordination and cooperation among ministries and departments;

f) renewal of approach in that it calls for greater involvement of voluntary organizations.

\section{Approaches in Community Development}

As mentioned in the preceding section, the community development approach in Malaysia focuses on four areas, viz., economy, education, health and social attitude. It has been explained to the people that the four areas are not meant to be taken in isolation nor are they exhaustive, they are interrelated. For instance, vigorous development through education, health and a more positive work attitude would certainly lead to economic betterment of the individual, family, 
community and the Malaysian society at large. Also, in addition to the four areas, there must be other areas of community development that are not less important in the context of multi-racial Malaysia.

Economy: Basically, the Malaysian community development approach in economy is attuned to the concept of "a just society" as described in the Rukunegara and the objectives of the New Economic Policy, namely, the eradication of poverty and the restructuring of society.

This does not, however, mean a denial of the economic advancement of the individual. It is accepted that, for the individual, development has significance only if it is related to his personal economic advancement. This concept of individual advancement is not questioned; except, that in the overall planning, national objectives must be given due consideration. Among schemes which are emphasised $\mathrm{f}_{\mathrm{F}}=$ economic development in Malaysia are:

a) Agricultural and industrial projects which will increase a person's productivity and income;

b) Projects which increase employment opportunities and skill training so as to reduce unemployment;

c) Projects which can support the urbanisation plan as referred to in the Second Malaysia Plan;

d) Projects which encourage indigenous groups participation in trade or commerce;

e) Projects which lend support to efforts by such bodies as the Farmers' Organization Authority, Cooperative Societies, Fishery Development Board, etc.

Education: The approach through education in the community development programme is looked at in terms of different age levels and social groups in the rural as well as urban areas. Among educational projects being emphasised in Malaysia are:

a) Projects to eliminate illiteracy in the national language;

b) Functional literacy which means when a person is able to read, he should use the knowledge gained to do his daily work better, which in turn may increase his income;

c) Pre-shool education for children. This programme should be considered from the angle of redressing the imbalance between the disadvantaged children and the advantaged ones in the towns. Apart from that, pre-school education schemes must also be considered from the view point of the process of socialization with the object of instilling patriotism and interracial understanding;

d) Family life education;

e) Religious and moral education;

f) Vocational education or work training which can help a person to obtain enployment or improve his skill and productivity;

g) Citizenship education which includes learning the national language, the country's history and constitution and the customs and culture of the various ethnic groups;

h) Library schemes throughout the country particularly in the rural areas and in the poorer areas in towns;

i) Education schemes for the sole purpose of increasing knowledge; 
j) Talks and dialogue sessions to explain government policies and programmes in national development.

Health: The community development approach from the health point of view is generally made through education, both formal and informal. Among health schemes and campaigns carried out for community involvement in Malaysia are:

a) Campaigns for the eradication and prevention of contagious diseases such as tuberculosis and malaria;

b) Cleanliness and environmental health campaigns especially relating to wells and latrines;

c) Applied Nutrition Programme which has a very wide concept and involvement;

d) Family Planning;

e) Mother and child health schemes;

f) Health campaigns generally through exhibitions and information.

Attitude: The community development approach in the above mentioned spheres must be accompanied by the formation of a positive attitude. It is common knowledge that attitude is the basis of hehaviour. Therefore, a positive attitude towards economic development, education and health must be formed or developed among the people.

In addition, "Operation Renewal" requires that the attitude of government officers involved in community development schemes must be improved. The involvement of those responsible at all levels of implementation will expedite development.

Patriotism among the people must be further improved. In this matter it is necessary to encourage citizenship education and to widen its definition to the largest extent, for instance, to cover matters regarding the development of national culture.

To facilitate planning and implementation of projects it has also been suggested that the word "community", in addition to its usual concept, be operationally defined in terms of more specific age-groups. This is to underline the point that regarding other than the overall community needs, one must be pragmatic and conscious of the fact that the community at different age-levels has different needs.

In addition, the planning of development projects in Malaysia needs to be considered also from the point of view of the various racial-groups both in the rural as well as the urban areas.

\section{Implementation Strategy}

The government recognizes the fact that in any effort to develop communities, it would be difficult to achieve success without initiative from and cooperation between both the government and the people. The people need guidance, support and opportunities to develop themselves. The government requires the cooperation and positive response from the people for the overall development of the community. Thus, it is obvious that the fusion of government effort and resources with those of the communities is a prerequisite to ensure the success of development. 
With community development being conceptualized in broader perspective, those ministries, departments and agencies operating specific ground development programmes such as agriculture, health, education, welfare services etc., need to be more aware of their roles. The implementation of community development programme cannot possibly be made to be the task of any single ministry or agency. The whole government machinery has to be geared to it. Further, they must be coordinated at the various levels so as to avoid unnecessary duplication of work as well as departmental rivalry.

Another strategy which is stressed in "Operation Renewal" is the involvement of voluntary organizations, service and welfare associations in community devevopment programmes. Youth bodies, women institutes, parent-teacher associations, religious groups and other local bodies are all encouraged to participate in community development work together with the Jawatankuasa Kemajuan Kampung. It is reckoned that such involvement and participation would further intensify development activities.

Local Level: According to "Operation Renewal", at local, village or area level, community development activities should be coordinated by the JKK. Therefore the government encourages the formation of this institution in places where there has been none, and in places where the JKK is dying to put a new life into it.

As regards members of the JKK, "Operation Renewal" prescribes that they should include one woman and one youth representative. In villages where the community is multiracial it is suggested that one of the members of the committee should be of another race. Membership of this pattern aims at encouraging the JKK to consider that goodwill, and good race relations in the community should be part of the community development programme.

Among the duties of the JKK as prescribed in "Operation Renewal" are:

1. To determine community development schemes to be implemented in the village;

2. Having determined the schemes, the JKK must decide on priorities. At the same time there may be a number of projects which can be implemented simultaneously;

3. To implement approved projects. The implementation can be carried out either by the village people themselves or in cooperation with government agencies/ departments or voluntary organizations etc.;

4. To take the initiative and implement successfully the approved projects especially from the following aspects:

a) "gotong royong", that is encouraging joint participation by the kampung people;

b) smooth progress of all projects being implemented;

c) preparing or helping to prepare the location etc. for the implementation of a project;

5. To act as liaison between the kampung people, the government and outside bodies;

6. To be jointly responsible with government bodies/departments or voluntary organizations for assessing development projects and thereafter to take necessary actions;

7. To make appropriate rules governing the appointment and duties of the Secretary of JKK; 
8. To keep all records of community development schemes including, among other things, minutes of meetings;

9. To invite anyone thought to be suitable because of his experience, work or ability to attend any Committee meeting;

10. To carry out any project or activity relevant to community development;

11. To hold regular meetings, preferably once a month.

District Level: To ensure cooperation and coordination in community development schemes as the district level, the government has decided that in each district, one of the Assistant District Officers is to be given the special duty of overseeing community development programmes. Among his duties are:

1. To plan and coordinate the implementation of community development schemes in the district;

2. To discuss and solve implementation problems encountered by government bodies or departments and voluntary organizations in the district;

3. To promote cooperation between government bodies or departments and voluntary organizations in or outside the district in the implementation of community development schemes;

4. To make assessment of the progress of community development schemes in the district;

5. To submit reports on community development schemes to the District Action

Committee;

6. To take appropriate action concerning community development schemes in accordance with the directions of the District Action Committee;

7. To prepare statements on aids channeled to certain community development projects;

8. To carry out any plan or activity considered relevant to community development;

9. To be the Secretary for the District Action Committee.

State Level: At the state level, it is suggested that community development schemes should be coordinated by the State Development Officer through the State Action Committee. Among the duties of the State Development Officer in relation to community development are:

1. To plan and coordinate the implementation of community development schemes in the whole state;

2. To discuss and solve implementation problems encountered by government bodies or departments and voluntary organizations in the state;

3. To promote cooperation between government bodies or departments and voluntary organizations in the state in the implementation of community development schemes;

4. To make assessment of the progress of community development schemes in the state;

5. To submit reports on community development schemes to the State Action Committee;

6. To take appropriate actions concerning community development schemes in accordance with the directions of the State Action Committee.

Central Level: At the central level, the State Development Officers will submit reports to the National Action Council through the Implementation Coordination and Development Administration Unit (ICDAU) of the Prime Minister's Depart- 
ment. This unit has also formed a coordination committee, namely, the Community Development Coordination Committee whose membership comprises officers from several ministries involved in community development programmes.

In addition to this main committee several sub-committees have also been formed to study certain problems of the community development plan so as to be able to make concrete recommendations for solving them.

"Operation Renewal" stresses the importance of training in the effort to intensify community development. Pre-service training and in-service training for officers serving in the community development field are given serious consideration. In addition, the government is also planning to provide training for non-government officials and workers who are involved in community development work such as village headmen, youth leaders, voluntary organization leaders etc.

Finally, in the "Operation Renewal" strategy, the government is also very much concerned with the evaluation of community development schemes or projects. Among the bodies considered appropriate to make continuous evaluation are:

a) District Development Committee;

b) State Development Committee;

c) Implementation Coordination and Development Administration Unit, Prime Minister's Department;

d) Ministries, departments, organizations involved in the implementation of community development projects. 
universal values may be - and in fact, often is - completely functional within an existing political and social context. Consequently, aid projects which are flawless in technical terms often fail because they do not consider the power structure of the political and economic system.

\section{Korea - The Constitutional Problems of a Divided State In Comparison with the Federal Republic of Germany}

\section{By Youn-Soo Kim}

From the beginning, the constitutional problems of the divided states of Korea and Germany have been different. While the division of Germany is a "perpetual reparation", the division of Korea was the result of a military action. Therefore, Korea still retains the necessary foundations for uniting the nation in the future i. e. Territory, People and Sovereignty remain undivided in the eyes of international law. On the other hand, Germany has totally lost these foundations because of the conditions set by the neighboring countries and by the superpowers. Thus, Germany now consists, according to international law, of two seperate sovereign nations.

Of course, the validity of German and Korean constitutions is limited to the "half-states". In Korea, this led to the North- and South-Korean dialogues and resulted in the North-South-Agreement of July 4th 1972, relating to the peaceful unification of Korea on the principle of a homogeneous nation. The first step after this agreement was the 1972 amendment of both Korean Constitutions. This first attempt was unsuccessful because of the internal problems of South Korea. Future success in the peaceful unification of Korea requires that both North and South Korea must first build Democracy in these countries.

\section{Community Development in Asia}

\section{By Udo ERnSt Simonis}

If professional conferences are to be regarded as an adequate indicator, community development (c. d.) should gain a new momentum in theory as well as in practice. Several international conferences on this subject have taken place recently; others are planned for next year. Its not difficult to believe that they have shown and will show more of the deficiencies of the c. d. concept than of its achievements.

According to a United Nations definition, community development is the process by which the efforts of the people themselves are united with those of governmental authorities to improve the economic, social, and cultural conditions of communities, to integrate these communities into the life of the nation and to enable them to contribute fully to national progress. Judging from the statements at one of these conferences, this UN term is still adhered to by most countries, especially the developing countries of Asia. The notion, however, of what c. d. actually should be about and the real contents and dimensions of the c. d. programmes differ widely from country to country. There are examples (and sometimes models) where the 
aims and instruments of c. d. are posed by a strong central administration, while others still rely (helplessly) on the idea of generating individual self-help; many countries and programmes are to be found somewhere in between these two.

A fairly long time has passed since the first c. d. programmes were introduced. It may therefore, well be worthwhile to start a new systematic comparative study of community development in general and of the different categories of c. d. programmes in particular. Though this cannot be done here, we do want, however, to spread empirical knowledge on c. d. work and have, therefore chosen to print three country reports (on the Republic of Korea, India, and Malaysia), which may show how c. d. is understood, where the approaches differ and what motive forces and vested interests are at stake.

The examples given may also indicate that a great deal of work has yet to be done on basic conceptual and methodological dimensions, including the revision of the UN definition of c.d. What for instance is "national progress" and "life of the nation". Whose "economic, social and cultural conditions should be improved" and whose not? Over what period and to what extent? What is "governmental authority" and how should it be legitimized?

A continual review of the practical experiences is certainly needed, especially with regard to concept, research and training in community development. Whether a renewed international effort on c.d. may also lead to a fundamental national and regional committment is, of course, a different matter. 